\title{
Temperature and its variability in oak forests in the southeastern Missouri Ozarks
}

\author{
Ming $\mathrm{Xu}^{1, *}$, Jiquan Chen ${ }^{1}$, Brian L. Brookshire ${ }^{2}$ \\ ${ }^{1}$ School of Forestry and Wood Products, Michigan Technological University, Houghton, Michigan 49931, USA \\ ${ }^{2}$ Missouri Department of Conservation, Jefferson City, Missouri 65102, USA
}

\begin{abstract}
This paper examines air and soil temperature, their variabilities, and their relationships with decomposition and ground flora diversity within an oak Quercus forest in the southeastern Missouri Ozarks (USA). We conducted 3 experiments with 9 mobile weather stations at Missouri Ozark Forest Ecosystem Project (MOFEP) study sites from September 1994 to August 1995. We used the cotton strip assay technique to quantify decomposition rate and Simpson's diversity index to evaluate the diversity of the ground flora. We found that air temperature at each site differed significantly from every other site $(p<0.001)$ based on a temporal scale of $20 \mathrm{~min}$; this was also the case for soil temperature $(\mathrm{p}<0.001)$. The spatial variation of soil temperature was consistently greater than that of air temperature. The spatial variation of air temperature increased with increasing spatial scale. Spatial variation of soil temperature increased rapidly from the 0 to ca $40 \mathrm{~m}$ scale, then decreased slowly before it began to increase again at a spatial scale of ca $700 \mathrm{~m}$. Temperature was not highly correlated to decomposition rate in the study area (correlation coefficients were 0.51 and 0.64 for air and soil temperature, respectively). The spatial variation of temperature was inversely related to the species diversity of the ground flora $\left(\mathrm{R}^{2}\right.$ was $0.87,0.93$, and 0.76 for air, soil surface, and soil temperature, respectively, at the $400 \mathrm{~m}$ scale). These results suggest that temperature variation can be quite significant, even at the stand level, and can impact some ecological patterns and processes at the same scale.
\end{abstract}

KEY WORDS: Forest microclimate - Ecological Land Type (ELT) - Missouri Ozark Forest Ecosystem Project (MOFEP) - Temperature variability - Scale issues

\section{INTRODUCTION}

Effective management of our environment and natural resources has become a major public concern in recent years. Ecosystem management has been proposed as one of the most promising avenues for addressing or resolving current environmental and natural resource issues (Haeuber \& Franklin 1996, Franklin 1997), as it is the integration of ecological, economic, and social factors in order to maintain and enhance economic output and the environmental quality of an ecosystem to meet current and future needs (Christensen et al. 1996, Thomas 1996). The Missouri Ozark Forest Ecosystem Project (MOFEP), initiated by the Missouri Department of Conservation in 1990, is a

\footnotetext{
-Present address: Department of ESPM, University of California at Berkeley, Berkeley, California 94720-3310, USA.

E-mail:mingxu@nature.berkeley.edu
}

pilot project designed to incorporate ecosystem management theories into forest management practices at the ecosystem level (Brookshire \& Hauser 1993). The project was designed to allow researchers, managers, and policy makers to cooperatively manage the ecosystems. As a long-term ecosystem research project, MOFEP is currently composed of 10 subprojects that focus on the following areas: (1) composition and spatial distribution of woody vegetation, (2) herbaceous plant species diversity, (3) forest bird diversity and productivity, (4) oak Quercus spp. mast production, (5) density and diversity of small mammals, reptiles and amphibians, (6) water movement and quality, (7) forest litter invertebrates, (8) genetic diversity in selected woody plants, (9) nutrient cycling, and (10) landscape ecology and microclimate. The current management design is scheduled to continue to the year 2055.

Many ecological phenomena are sensitive to spatial heterogeneity and fluxes within spatial mosaics. For 
example, gene flow and population differentiation respond well to spatial heterogeneity (Futuyma 1986). Landscape ecology has provided new ways to explore spatial heterogeneity, to discover how spatial patterns control ecological processes at various scales, and to answer questions which traditional within-patch explanations address incompletely (Pickett \& Cadenasso 1995). Over the long term, environmental diversity determines biological diversity. Environmental heterogeneity is an important factor in the process of adaptive evolution, and it may contribute to the maintenance of genetic polymorphism in natural populations. Field investigations have implicated spatial variation as an important component in the maintenance of genetic variation at the chromosomal and enzymatic levels (Taylor \& Powell 1977, Mulley et al. 1979, Barker et al. 1987). Previous studies have also demonstrated that environmental patterns are related to species distribution and vegetation types (Zabel et al. 1976).

Since climate is one of the most important environmental factors, climatic variation may play a critical role in such ecological phenomena and processes as species distribution, composition and diversity, regeneration, and productivity (Zobel et al. 1976, Johansson et al. 1995). At large spatial scales (e.g. global or regional level), the effect of macroclimate is dominant. However, at small scales (stand or individual tree level) using macroclimate may lead to over-generalization. In this case, microclimate is much more important because it directly influences most ecological and physiological processes (Waring \& Schlesinger 1985, Chen \& Franklin 1997). A simple reason for adding microclimate research to MOFEP was to provide microclimate data to the other subprojects and, as an input, to the ecosystem management models. Using microclimate data may improve the accuracy and application of the models because of the heterogeneous nature of microclimate. Evaluating how the different management treatments influence the local climate and monitoring the long-term microclimatic variation are essential objectives of this project.

Among various microclimate variables, temperature is one of the most critical factors. Temperature and its variation govern most biological and ecological processes, and in some cases the latter may be more important (Alexander 1961). In addition, temperature affects photosynthesis, respiration, bud opening, shoot growth, seedling mortality, and seed germination (Zimmermann et al. 1971, Kramer \& Kozlowski 1979, Sorensen 1983, Kanninen 1985, Kuhns et al. 1985). Although seeds of many species will germinate at constant temperature, germination of most species requires or is increased by temperature fluctuations (e.g. Manchurian ash and Japanese red pine) (Hatano \& Asakawa 1964, Kramer \& Kozlowski 1979). Further- more, temperature and its variation significantly influence the composition, growth and productivity of microorganisms. Both autotrophic and heterotrophic organisms might thrive better with fluctuating than with constant temperature (Brock 1966). Wildlife is also affected by temperature and its variation, in activities such as habitat selection, migration, and the internal chemical systems through which animals regulate their body temperature (Gordon et al. 1977, Hunter 1990).

Previous studies have shown that spatial and temporal variations in temperature are significant in differentiating vegetation zones, species composition and populations at large spatial and temporal scales (Wilson 1970, Bergen 1974). Little attention has been paid to small scales, such as the stand and substand levels (Zobel et al. 1976, Chen \& Franklin 1997). Because the spatial heterogeneity at various scales in ecological systems often influences different ecological processes (Pickett \& Cadenasso 1995) and because both biotic and abiotic elements of an ecosystem change almost continuously both in space and in time, we expect that temperature and its variability at small scales may be critical to some ecological patterns and processes in ground flora and forest soil, though probably not to the overstory. Unfortunately, it is not clear how the spatial variation of temperature is related to some ecological phenomena and processes at the stand and substand levels (e.g. species distribution, composition and diversity, ground flora, microorganisms, soil animals, and decomposition). We know little about temperature and its variation at these scales.

Earlier studies of forest microclimate have focused on the effects of individual factors, such as topographic position, soil type, vegetation type, or different harvesting methods (Waring 1969, Wilson 1970, Hungerford \& Babbit 1987). However, current ecosystem management practices are based on a more comprehensive ecological unit, such as the Ecological Land Type (ELT) or Land Type Association (LTA). Thus, microclimatic information must be based on current ecological units in order to be useful to managers.

Ecological land classification, a hierarchically structured, multifactor approach for mapping ecological units at multiple scales, has been shown to be helpful in quantifying variation in fundamental ecological processes and in management operations (Barnes et al. 1982, Spies \& Barnes 1985, Zak et al. 1986, Host et al. 1988, 1996, Davis \& Dozier 1990, Hanson \& Hargrave 1996). A commonly used system in the United States has been developed by the U.S. Department of Agriculture Forest Service, the National Hierarchical Framework of Ecological Units (ECOMAP 1993), which includes 8 ecological units. This system has been extensively adopted by other national (e.g. 
National Park Service), regional, (e.g. Lake States, Pacific Northwest) and state (e.g. Missouri and Montana) natural resource management agencies (Davis \& Dozier 1990, Lowell 1990, Hanson \& Hargrave 1996 Host et al. 1996). Level 7 of this system is the Ecological Land Type (ELT), which is defined as an ecologically uniform area capable of a particular level of production or use and characterized by regional landform, soil type, topographic aspect, slope steepness, and natural vegetation (USDA 1979, Miller 1981, Lowell 1990, Albert 1995). To make our results more valuable to the MOFEP project we also compared temperature and its variability between 3 dominant ELTs at the MOFEP sites.

The objectives of this paper are to examine: (1) temperature and its spatial variation at a small scale $(80 \times$ $80 \mathrm{~m}^{2}$ ) within ELT 17 ; (2) temperature and its variability among ELTs 11, 17, and 18 (stand level); (3) changes in temperature variation with spatial and temporal scales; and (4) relationships between temperature variation and some ecological phenomena and processes at the stand level (e.g. decomposition and species diversity).

\section{METHODS}

2.1. Study area. The MOFEP study area is made up of 9 compartments, ranging in size from 260 to 527 ha, which are located in Carter, Reynolds, and Shannon counties in the southeastern Missouri Ozarks $\left(91^{\circ} 01^{\prime}\right.$ to $91^{\circ} 13^{\prime} \mathrm{W}$ and $37^{\circ} 00^{\prime}$ to $37^{\circ} 12^{\prime} \mathrm{N}$ ). These counties are $84 \%$ forested with large contiguous blocks separated only by roads and streams. Agricultural activities are limited to bottomland corridors along primary streams. The study area consists of mature upland oakhickory and oak-pine forest communities. Dominant tree species include white oak Quercus alba L., black oak Quercus velutina L., post oak Quercus stellata Wang, scarlet oak Quercus coccinea Muenchh., blackjack oak Quercus marilandica Muenchh., chinkapin oak Quercus muehlenbergii Engelm, shortleaf pine Pinus echinata Mill., and hickory Carya spp. Understory species include dogwood Cornus spp. and blackgum Nyssa sylvatica.

Geologically, this region is underlain mainly by Ordovician age dolomite with areas of Cambrian age dolomite. Precambrian igneous rocks are also present (Missouri Geological Survey 1979). Weathering of the Ordovician and Cambrian age dolomites has resulted in a deep mantle of leached very cherty residuum on the MOFEP study sites (Gott 1975). Soils in this area were formed mostly in residuum. The common series is Viburnum, Midco, Gepp, Bardley, Viraton, Poynor and Clarksville (Brookshire \& Hauser 1993). Mean annual temperature and annual precipitation are $13.3^{\circ} \mathrm{C}$ and $1120 \mathrm{~mm}$, respectively. The MOFEP study sites cover 13 different ELTs, with ELTs 11,17 and 18 comprising $90 \%$ of the total area (Table 1 ).

2.2. Experimental design and instrumentation. Three experiments were conducted in 1994 and 1995 (Table 2). The first experiment examined temperature and its variability on a small spatial scale $\left(80 \times 80 \mathrm{~m}^{2}\right)$ within ELT 17. Specifically, it was conducted to test whether temperature varied significantly within the same ELT. In addition, this experiment examined the mean temperature, vertical profile of temperature, spatial and temporal variation of temperature, and diurnal temperature patterns during the measurement period (June 15 to 30,1995$)$. Nine weather stations were installed on the slope within an $80 \times 80 \mathrm{~m}^{2}$ square area, with $40 \mathrm{~m}$ spacing between each station. The second experiment compared temperature and its variability among 3 dominant ELTs $(11,17$ and 18) at a medium spatial scale $(<3 \mathrm{~km})$. Three weather stations were installed within each ELT at different locations where 3 different treatments (unchanged, partial cut, and group opening) would be applied to evaluate effects of silvicultural treatments on ecosystem processes. Data collected at the 3 stations before the silvicultural treatments were treated as 3 replicates. Data collection lasted for $14 \mathrm{~d}$ (August 11 to 25, 1995). The third experiment examined temperature and its variation on larger temporal (about 1 yr) and spatial (about $20 \mathrm{~km}$ ) scales. A weather station was randomly located at each of the 9 MOFEP sites. Data collection started in September 1994 and lasted to early April 1995.

A $10 \mathrm{~m}$ radius circular plot was established around each station to record DBH [diameter at breast height $(1.37 \mathrm{~m})]$, overstory density $(\mathrm{DBH} \geq 6 \mathrm{~cm}$, stems ha-1), understory density $(3 \mathrm{~cm} \leq \mathrm{DBH}<6 \mathrm{~cm}$, stems ha-1) and canopy coverage (using a GRS densitometer; Forestry Suppliers, Inc.). Table 2 summarizes the veg-

Table 1. Description of 3 major ELTs $(11,17$ and 18$)$ in MOFEP study sites that were selected for comparison in Expt 2 of this study

\begin{tabular}{|lllcll|}
\hline ELT Land form & Aspect & Slope (\%) & Soil series & Vegetation community \\
\hline 11 & Ridge & Neutral & $0-8$ & $\begin{array}{l}\text { Clarksville, } \\
\text { Poynor, Gepp }\end{array}$ & Dry chert forest \\
17 & Side slope & $\begin{array}{l}\text { South and } \\
\text { West }\end{array}$ & $8-99$ & $\begin{array}{l}\text { Clarksville, } \\
\text { Poynor, Gepp }\end{array}$ & Dry chert forest \\
18 & Side slope & $\begin{array}{l}\text { North and } \\
\text { East }\end{array}$ & $8-99$ & $\begin{array}{l}\text { Clarksville, Dry-mesic chert forest } \\
\text { Poynor, Gepp }\end{array}$ & Dry-mesic sand forest \\
\hline
\end{tabular}


Table 2. Vegetation and topographic conditions of each experimental station. DBH: diameter at breast height

\begin{tabular}{|c|c|c|c|c|c|c|c|c|}
\hline Expt & Stn & ELT & $\begin{array}{l}\text { Slope } \\
(\%)\end{array}$ & $\begin{array}{c}\text { Aspect } \\
\left({ }^{\circ}\right)\end{array}$ & $\begin{array}{r}\text { Density } \\
\mathrm{DBH} \geq 6 \mathrm{~cm}\end{array}$ & $\begin{array}{l}\text { tems ha-1) } \\
3 \leq \mathrm{DBH}<6 \mathrm{~cm}\end{array}$ & $\begin{array}{l}\mathrm{DBH} \\
(\mathrm{cm})\end{array}$ & $\begin{array}{c}\text { Coverage } \\
(\%)\end{array}$ \\
\hline \multirow[t]{9}{*}{1 (Jun $15-30,1995)$} & 1 & 17 & 10 & 205 & 1011 & 414 & 17.95 & 80.55 \\
\hline & 2 & 17 & 8 & 205 & 891 & 1273 & 17.76 & 77.60 \\
\hline & 3 & 17 & 15 & 200 & 637 & 637 & 19.28 & 81.02 \\
\hline & 4 & 17 & 15 & 195 & 1273 & 446 & 15.84 & 82.74 \\
\hline & 5 & 17 & 10 & 190 & 859 & 859 & 15.96 & 70.17 \\
\hline & 6 & 17 & 18 & 190 & 1719 & 1178 & 13.51 & 76.05 \\
\hline & 7 & 17 & 20 & 185 & 1273 & 796 & 13.01 & 79.76 \\
\hline & 8 & 17 & 10 & 180 & 1655 & 1050 & 15.33 & 85.12 \\
\hline & 9 & 17 & 10 & 180 & 1432 & 1655 & 13.28 & 85.81 \\
\hline \multirow[t]{9}{*}{2 (Aug 11-25, 1995) } & 1 & 18 & 20 & 0 & 828 & 796 & 22.91 & 82.64 \\
\hline & 2 & 18 & 20 & 0 & 1241 & 1210 & 17.45 & 80.90 \\
\hline & 3 & 18 & 20 & 10 & 1019 & 1146 & 18.65 & 79.40 \\
\hline & 4 & 11 & 3 & 0 & 1146 & 350 & 19.57 & 82.52 \\
\hline & 5 & 17 & 25 & 190 & 891 & 637 & 20.55 & 84.76 \\
\hline & 6 & 11 & 3 & 0 & 1019 & 95 & 20.07 & 79.48 \\
\hline & 7 & 17 & 28 & 205 & 828 & 446 & 22.73 & 81.20 \\
\hline & 8 & 17 & 25 & 210 & 637 & 447 & 21.93 & 82.52 \\
\hline & 9 & 11 & 4 & 0 & 1019 & 191 & 19.14 & 80.43 \\
\hline \multirow{9}{*}{$\begin{array}{r}3(\text { Sep } 13,1994- \\
\quad \text { Mar 30, 1995) }\end{array}$} & 1 & 11 & 3 & 0 & 923 & 604 & 20.59 & 75.60 \\
\hline & 2 & 17 & 20 & 230 & 1273 & 382 & 15.13 & 79.21 \\
\hline & 3 & 18 & 26 & 135 & 1114 & 382 & 21.29 & 82.64 \\
\hline & 4 & 17 & 30 & 230 & 891 & 732 & 20.94 & 78.45 \\
\hline & 5 & 17 & 38 & 290 & 828 & 828 & 20.51 & 77.02 \\
\hline & 6 & 18 & 27 & 0 & 796 & 255 & 22.24 & 78.13 \\
\hline & 7 & 11 & 2 & 0 & 1942 & 223 & 12.37 & 78.45 \\
\hline & 8 & 11 & 3 & 0 & 477 & 573 & 26.46 & 72.98 \\
\hline & 9 & 18 & 25 & 320 & 859 & 541 & 15.12 & 82.38 \\
\hline
\end{tabular}

etational and topographic information for each station in each experiment.

The cotton strip assay technique was used to determine the decomposition rates in the forest. The cotton strip assay technique is a quick and simple method for determining relative differences in cellulose decomposition rate. Five $12 \times 15 \mathrm{~cm}$ strips of Shirley Burial Cloth manufactured by Shirley Dyeing and Finish Ltd. (Sagar 1988) were inserted vertically into the soil to a depth of $12 \mathrm{~cm}$ at each station in Expt 1 using the method outlined by Latter \& Walton (1988). The cotton strips remained in the field for $6 \mathrm{wk}$ before they were removed for analysis. We used a Scanpro Alwetron TH-1 tensile strength tester to determine the strength $\left(\mathrm{kN} \mathrm{m}^{-1}\right)$ of different parts of a strip through the soil profile. Differences in tensile strength loss were taken to represent the relative rates of decomposition (Heal et al. 1974, Inerson et al. 1988, Day 1995).

Microclimatic variables monitored at each station included solar radiation, wind speed, relative humidity, soil temperature at $0,5,10,15$, and $20 \mathrm{~cm}$ in the soil, and air temperature at $0,0.5,1.0,1.5$, and $2.0 \mathrm{~m}$ above the ground. Since microclimate might have more influence on herbs and ground flora than on the overstory, and because most important soil processes (e.g. horizontal rooting) occur between 5 and $20 \mathrm{~cm}$ from the soil surface (Faulkner 1976, Dickmann \& Pregitzer 1992), we chose air temperature at $1.0 \mathrm{~m}$ above the soil surface and soil temperature at $5 \mathrm{~cm}$ depth to represent the air temperature $\left(T_{d}\right)$ and soil temperature $\left(T_{\varsigma}\right)$ in this study. T-type thermocouples were used to measure soil temperature, and E-type thermocouples were used to measure air temperature. Campbell dataloggers (21X and CR10) were programmed to sample data every $10 \mathrm{~s}$ and to record $20 \mathrm{~min}$ average values. Toshiba T1200 and T1000 portable computers and SC32A interfaces were used for programming and data retrieval. Two permanent weather stations were installed in the experimental area, one in a forest opening and the other in a closed canopy forest. The purposes of the 2 permanent stations were: (1) to estimate any missing data resulting from technical failures at mobile stations; (2) to compensate for the limitation of sampling locations and times; and (3) to evaluate longterm microclimatic characteristics (seasonal, annual, or longer).

Since the installation of weather stations inevitably damages the ground flora and soil, it reduced our ability to examine relationships between temperature and vegetation in the above 3 experiments. For this reason, 
we established a $900 \mathrm{~m}$ transect through the study area during the 1996 growing season. Every $10 \mathrm{~m}$ along the transect we sampled air temperature at $1.0 \mathrm{~m}$ above the soil surface and soil temperatures at the surface and $5 \mathrm{~cm}$ depth using custom-built thermocouple sensors. A $1 \times 1 \mathrm{~m}^{2}$ vegetation plot was sampled at each point to record species and coverage of the ground flora, height and DBH of the 4 trees closest to the plot center, and overstory coverage. We also estimated the coverages of litter, bare soil, rock, moss, and coarse woody debris (CWD).

2.3. Data analysis. Field data from each experiment usually displayed trends over time (hourly, daily, monthly, seasonal, or yearly) and were often highly autocorrelated. Therefore, the data had to be transformed before it could be used to test for differences between stations or ELTs. The data transformation was performed by subtracting the mean of the 9 stations from the original data $[X(t)]$ at any given time $(t)$, namely:

$$
T(t)=X(t)-\sum_{i=1}^{n} X(t) / n
$$

where $T(t)$ is the transformed temperature and $n$ is the number of stations. Parametric statistics (e.g. ANOVA and regression analysis) were primarily used in this study. If the transformed data did not meet the assumptions of normality and homogeneous variance, the Kruskal-Wallis nonparametric test was used instead (Gibbons 1985).

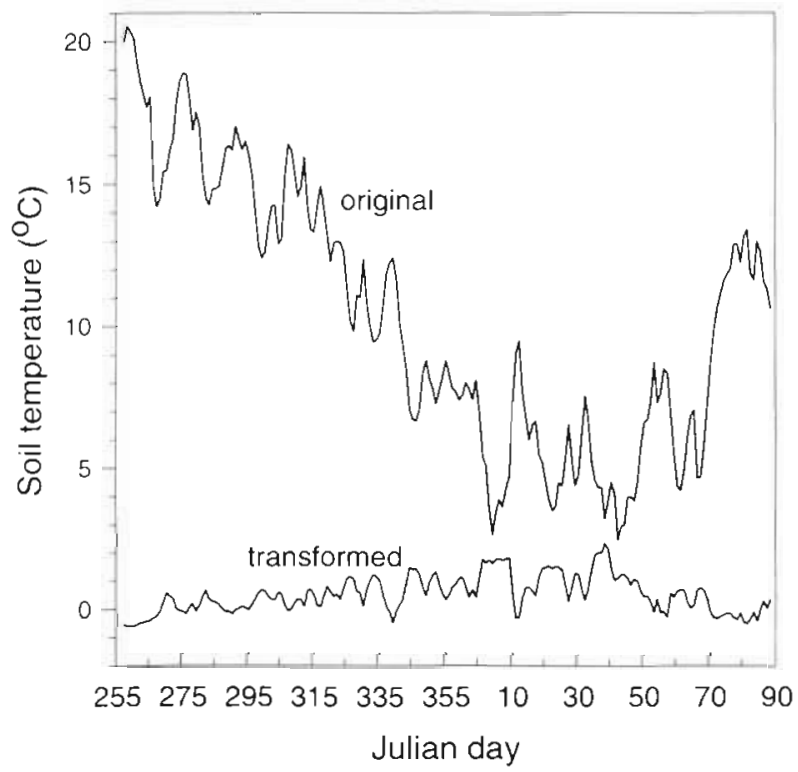

Fig. 1 Data transformation of daily average soil temperature at Stn 1 (Expt 3) from fall 1994 to spring 1995. The seasonal trend in the original data was removed after transforming the data by subtracting the mean of the 9 stations at each time point
Fig. 1 shows the effectiveness of the data transformation. The original data in Fig. 1 are soil temperatures at Stn 1 (Expt 3) from fall 1994 to spring 1995. The seasonal pattern of the original data is obvious: decreasing from fall to winter, and increasing from winter to spring. After transformation the seasonal trend is almost eliminated. We used sample standard deviation to quantify the temperature variation. Simpson's diversity index $(S)$ was calculated for each vegetation plot along the transect as:

$$
S=-\ln \sum_{i=1}^{n} p_{i}^{2}
$$

where $n$ is the number of species in each plot, and $p_{i}$ is the proportion of coverage of species $i$. Correlation and regression analyses were performed to detect the relationships between temperature (or temperature variation) and diversity at multiple spatial scales along the transect.

\section{RESULTS}

\subsection{Temperature and its variability within ELT 17}

The spatial heterogeneity of temperature was statistically significant even at a small spatial scale $(80 \times$ $\left.80 \mathrm{~m}^{2}\right)$. At the temporal scale of $20 \mathrm{~min}$, air temperatures differed significantly between the 9 stations $(p<$ $0.001)$, as did the soil temperature $(p<0.001)$. The differences between any 2 stations were also significant $(\mathrm{p}<0.05)$, according to Student-Newman-Keuls multiple comparison tests.

Soil temperature showed a larger spatial variation $\left(1.3\right.$ to $\left.2.5^{\circ} \mathrm{C}\right)$ than air temperature $\left(0.7\right.$ to $\left.1.6^{\circ} \mathrm{C}\right)$ during the measurement period. The changes in spatial variation of air and soil temperatures over time were similar, but the spatial variation of soil temperature lagged air temperature by about 20 min (Fig. 2). Based on Expt 1, the spatial variation of soil temperature was highly correlated with that of air temperature:

$$
\sigma_{\mathrm{s}}=0.439+1.3467 \sigma_{\mathrm{a}} \quad\left(\mathrm{R}^{2}=0.83\right)
$$

where $\sigma_{s}$ is the spatial variation of soil temperature at $t_{1}$, and $\sigma_{\mathrm{a}}$ is the spatial variation of air temperature at $t_{0}$ (20 min earlier).

The temporal variation of air temperature was about $4^{\circ} \mathrm{C}$, but only about $1^{\circ} \mathrm{C}$ for soil temperature during the measurement period. However, they were highly correlated by a linear regression equation:

$$
\sigma_{\mathrm{s}(t)}=-2.978+1.0225 \sigma_{\mathrm{a}(t)} \quad\left(\mathrm{R}^{2}=0.74\right)
$$

where $\sigma_{s(t)}$ is the temporal variation of soil temperature, and $\sigma_{a(t)}$ is the temporal variation of air temperature. This quantitative relationship may change with soil 


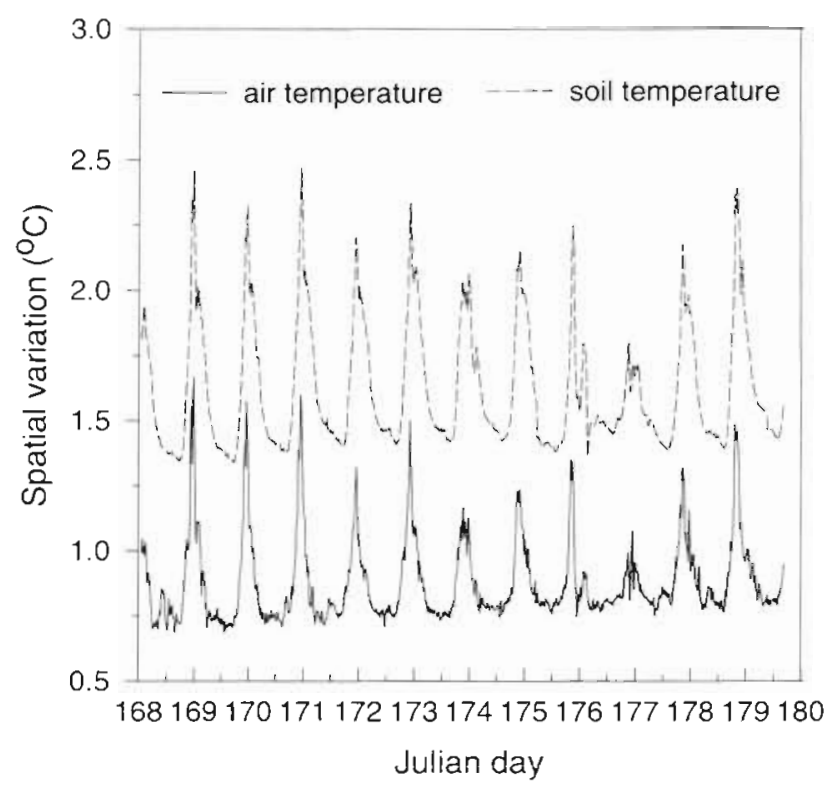

Fig. 2. Spatial variation of air and soil temperature within ELT 17 in Expt 1 (June 15 to 30, 1995)

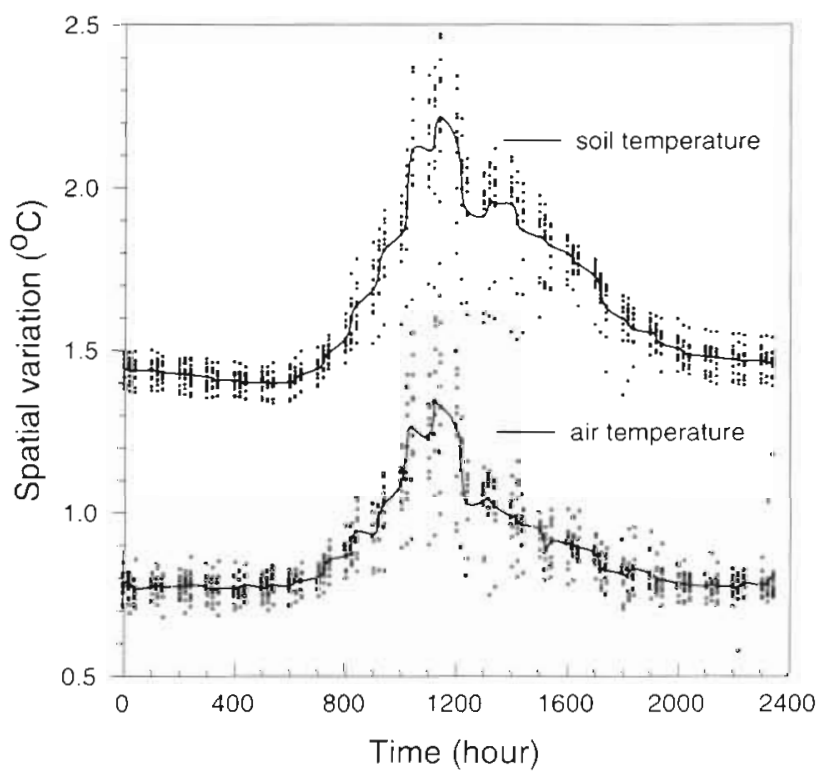

Fig. 3. Diurnal pattern of the spatial variation within ELT 17 in Expt 1 (June 15 to 30,1995 )

temperature at different depths and air temperature at different heights.

The diurnal patterns of spatial variation of air and soil temperature were similar (Fig. 3). The spatial variation of soil temperature was consistently $\left(0.6\right.$ to $\left.0.9^{\circ} \mathrm{C}\right)$ higher than that of air temperature at any time of day. The highest spatial variation occurred between 10:00 and 12:00 h and the lowest variation at about 06:00 h.

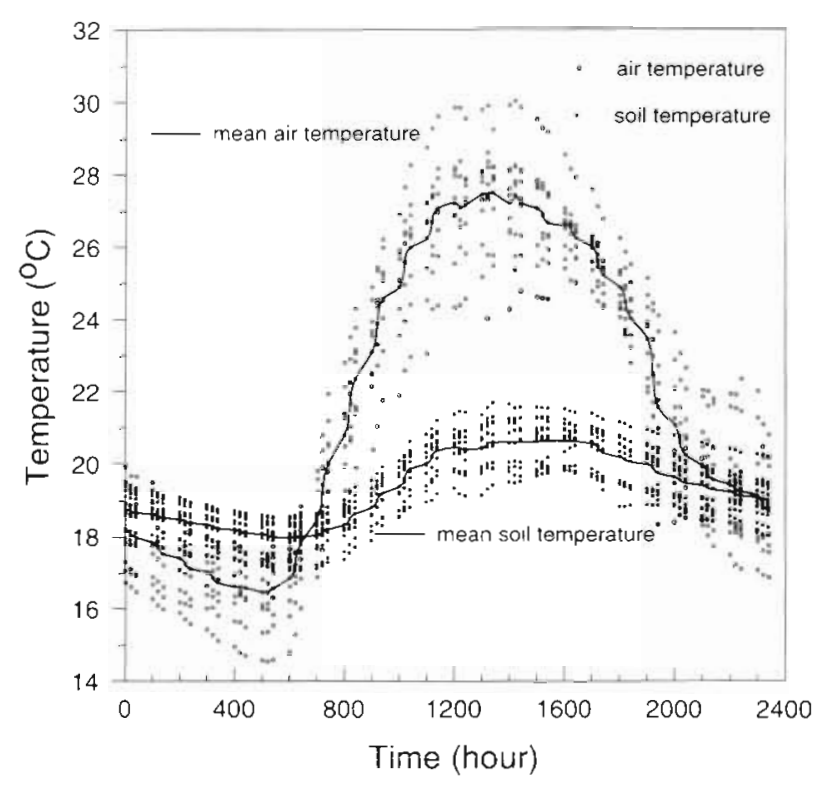

Fig. 4. Diurnal pattern of air and soil temperature within ELT 17 in Expt 1 (June 15 to 30, 1995)

Soil temperature lagged air temperature by about $20 \mathrm{~min}$. The spatial variation of temperature was smaller and more stable during the night (from 20:00 to 06:00 h) than during the day. The spatial variation of soil temperature remained relatively high in the afternoon (12:00 to 19:00 h), whereas the spatial variation of air temperature decreased more quickly during the same period. The highest values of air and soil temperature occurred at about 13:00 and 14:00 h respectively (Fig. 4), but the highest spatial variation occurred around 11:00 h (Fig. 3), so temperature and its spatial variation did not keep the same diurnal pace.

Average air temperature was higher than average soil temperature at each station, with a strong positive linear relationship between them. Based on data from Expt 1, the mean, minimum, and maximum soil temperatures can be estimated from the mean, minimum, and maximum air temperatures respectively:

$$
\begin{array}{lll}
\mathrm{TS}_{\text {mean }}=-21.0968+1.8937 \mathrm{TA}_{\operatorname{mean}} & \left(\mathrm{R}^{2}=0.97\right) \\
\mathrm{TS}_{\min }=-10.2836+1.8805 \mathrm{TA}_{\min } & \left(\mathrm{R}^{2}=0.96\right) \\
\mathrm{TS}_{\max }=-26.4889+1.6018 \mathrm{TA}_{\max } & \left(\mathrm{R}^{2}=0.85\right)
\end{array}
$$

where $\mathrm{TS}=$ soil temperature and $\mathrm{TA}=$ air temperature.

The mean soil temperature increased linearly from $20 \mathrm{~cm}$ depth to the surface. Temperature increased rapidly near the soil surface, and then decreased slowly with increasing height above the ground (Fig. 5). The mean soil temperatures at different depths $(0,5,10,15$, and $20 \mathrm{~cm})$ were significantly different $(\mathrm{p}<0.001)$. However, differences between the mean air temperatures at different heights $(0,0.5,1.0,1.5$, 


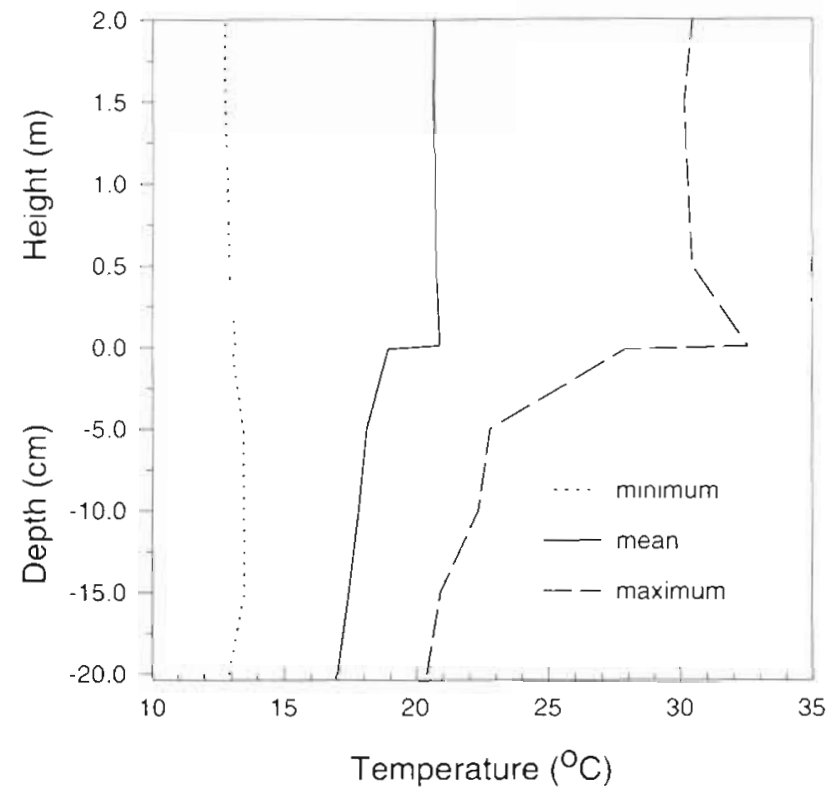

Fig. 5. Vertical profile of the mean, minimum, and maximum temperatures (in Expt 1) from $20 \mathrm{~cm}$ depth in the soil to $2 \mathrm{~m}$ above the soil surface

and $2.0 \mathrm{~m}$ ) were not statistically significant $(p>0.27$ ). The vertical profile of minimum and maximum temperature exhibited the same trend as the mean temperature. But the minimum temperature changed less along the vertical gradient, while the change in the maximum temperature was greater, especially near the soil surface (Fig. 5).

The diurnal pattern of air temperature was typically bell-shaped, but that of soil temperature was much 'flatter' (Fig. 4). The average daily difference was about $11^{\circ} \mathrm{C}$ for air temperature and only about $2^{\circ} \mathrm{C}$ for soil temperature. Air temperature was higher than soil temperature during the day, but lower at night. Air temperature equaled soil temperature twice a day, once at about 07:00 h (local standard time), and again at about 23:00 h. Air temperature reached its maximum around 13:00 $\mathrm{h}$ and minimum around 05:00 h. Soil temperature reached its highest value around 14:00 h, and its lowest value around 06:00 h. Soil temperature lagged air temperature by about $1 \mathrm{~h}$ (Fig. 4).

\subsection{Temperature and its variability between ELTs 11, 17 and 18}

The spatial variations of soil and air temperature increased from within a single ELT (Expt 1) to among 3 ELTs (Expt 2) (Figs. 2 \& 6A). The spatial variation of soil temperature $\left(1.6\right.$ to $\left.2.5^{\circ} \mathrm{C}\right)$ was significantly higher than that of air temperature $\left(0.8\right.$ to $\left.2.3^{\circ} \mathrm{C}\right)$ between different ELTs $(p<0.001)$ (Fig. $6 \mathrm{~A})$, and the spatial varia- tion of air temperature and that of soil temperature were poorly correlated $\left(\mathrm{R}^{2}=0.27\right)$. The spatial variation of soil temperature was quite stable during the night, reaching its minimum value at about $07: 00 \mathrm{~h}$, and then increasing in the morning. It decreased from 12:00 to 14:00 h, reached its maximum value at about 15:00 h, and then decreased again (Fig. 6B). The spatial variation of air temperature decreased during the night to its minimum value at 08:00 h, then increased in the morning. It reached its first peak value at about 13:00 $\mathrm{h}$, then decreased sharply, before increasing to the second peak value at about 14:00 h. Afterwards, it decreased until 17:00 $\mathrm{h}$, then increased to the third peak value at about 21:00 h (Fig. 6B). The largest difference between the spatial variations of air temperature and soil temperature occurred in the early morning, not at midday (Fig. 6B).

The mean temporal variations of air temperature in ELTs 11,17 and 18 were $4.09,4.82$, and $4.04^{\circ} \mathrm{C}$, respectively. The corresponding values for soil temperature were $1.16,1.57$, and $1.22^{\circ} \mathrm{C}$ (Fig. 7).

Air temperatures were similar in ELTs 11 and 17 , but substantially lower in ELT 18 (Fig. 8A). The mean air temperatures in ELTs 11,17 and 18 were 26.76, 26.08, and $24.12^{\circ} \mathrm{C}$, respectively. However, the corresponding daily differences (maximum minus minimum) of air temperature were $21.09,22.28$, and $19.7^{\circ} \mathrm{C}$ (Table 3 ). Mean air temperature was significantly different $(p<$ 0.001 ) between the ELTs. The patterns of air temperature in ELTs 11,17 and 18 were similar (Fig. 8A). The soil temperature in ELT 17 was consistently higher than that in ELT 11, and the soil temperature in ELT 18 was obviously lower than those in ELT 11 and 17 (Fig. 8B). The average soil temperatures in ELT 11, 17 and 18 were $23.29,24.29$, and $20.66^{\circ} \mathrm{C}$, respectively. The average daily differences of soil temperature were $6.21,7.76$, and $5.9^{\circ} \mathrm{C}$, respectively (Table 3 ). The mean soil temperature was significantly different between the ELTs $(p<0.001)$. The patterns of soil temperature were different: ELT 17 was sharper than ELT 11, and ELT 11 was sharper than ELT 18 (Fig. 8B). The mean soil temperature ( 20 min average) in each ELT can be estimated by the corresponding air temperature:

$$
\begin{array}{ll}
\text { TS11 }=16.3476+0.2592 \text { TA } 11 & \left(R^{2}=0.82\right) \\
\text { TS17 }=16.1572+0.3112 \text { TA } 17 & \left(R^{2}=0.92\right) \\
\text { TS18 }=13.9778+0.2764 \text { TA18 } & \left(R^{2}=0.84\right)
\end{array}
$$

where TS11, TA11, TS17, TA17, TS18, and TA18 are the corresponding soil and air temperatures in ELTs 11,17 and 18 , respectively. Soil temperature lagged air temperature by 60, 80, and $100 \mathrm{~min}$ in ELT 11, 17 and 18 respectively.

The diurnal patterns of air temperature in ELTs 11, 17 and 18 were different. The difference between ELTs 11 and 17 was smaller than those between ELTs 18 and 11 

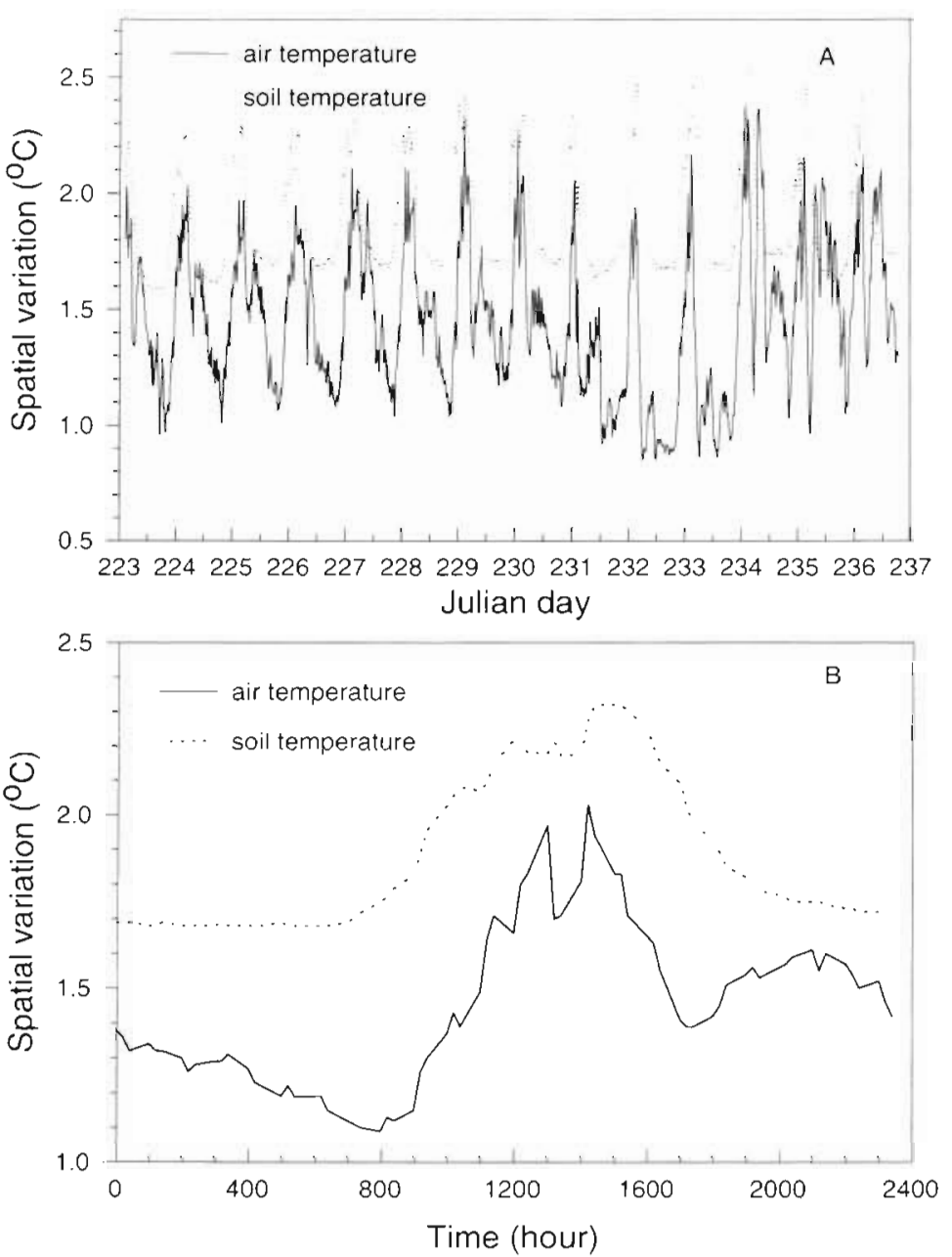

\subsection{Temperature and its variability at larger spatial and temporal scales}

Unlike Expt 1 and Expt 2 (stand level) the spatial variation of air temperature in Expt 3 (landscape scale) was generally higher than that of soil temperature during the measurement period (Fig. 10C, D). The spatial variation of air temperature did not show a clear seasonal trend, while the spatial variation of soil temperature decreased from September to December 1994, and then remained relatively stable (Fig. 10C, D)

Both air and soil temperature were significantly different among the 9 MOFEP sites ( $\mathrm{p}<$ 0.001). Multiple comparison tests (StudentNewman-Keuls) showed that any 2 sites were significantly different from each other $(p<$ 0.01 ). A clearly decreasing trend can be seen from September 1994 to early January 1995 for both air and soil temperature, followed by an increase (Fig. 10A, B). Soil temperature was generally higher than air temperature from October to February. During the measurement period the maximum air temperature was close to $28^{\circ} \mathrm{C}$, and the maximum soil temperature was about $23^{\circ} \mathrm{C}$, both of which occurred in September. The minimum air temperature was close to $-20^{\circ} \mathrm{C}$, and the minimum soil temperature was about $2^{\circ} \mathrm{C}$, both of which occurred in early January (Fig 10A, B).

Fig. 6. Spatial variations of air and soil temperature and their diurnal patterns between different ELTs in Expt 2 (August 11 to 25, 1995)

and between ELTs 18 and 17 (Fig. 9A). The minimum air temperature occurred at about 06:00 h. The maximum air temperature occurred at about 13:00 h, a little earlier for ELT 18 (Fig. 9A). The air temperature in ELT 11 was higher than that in ELT 17 during the night but similar during the day, especially in the morning. The air temperature in ELT 18 was consistently lower than in ELT 11 and 17 throughout the day. The curves of soil temperature were 'flatter' than those of air temperature (Fig, 9A, B). The minimum soil temperature occurred at about $07: 00 \mathrm{~h}$. The maximum soil temperature occurred at about 13:00 h for ELT 18, about 14:00 h for ELT 11, and around 15:00 h for ELT 17 (Fig. 9B). The soil temperature was consistently the highest in ELT 17 and the lowest in ELT 18 throughout the day (Fig. 9B). The diurnal pattern of soil temperature in each ELT was asymmetric: the soil temperature in ELTs 11 and 18 increased faster in the morning than it decreased in the afternoon; the opposite occurred in ELT 17 (Fig. 9B).

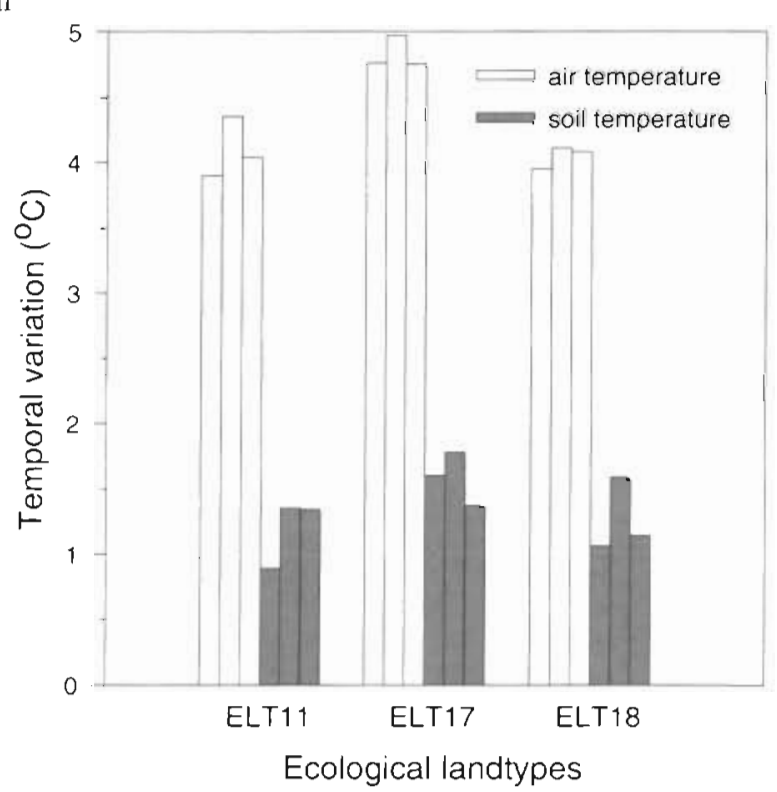

Fig. 7 Comparison of the temporal variation of air and soil temperature between different ELTs in Expt 2 (August 11 to 25,1995$)$ 


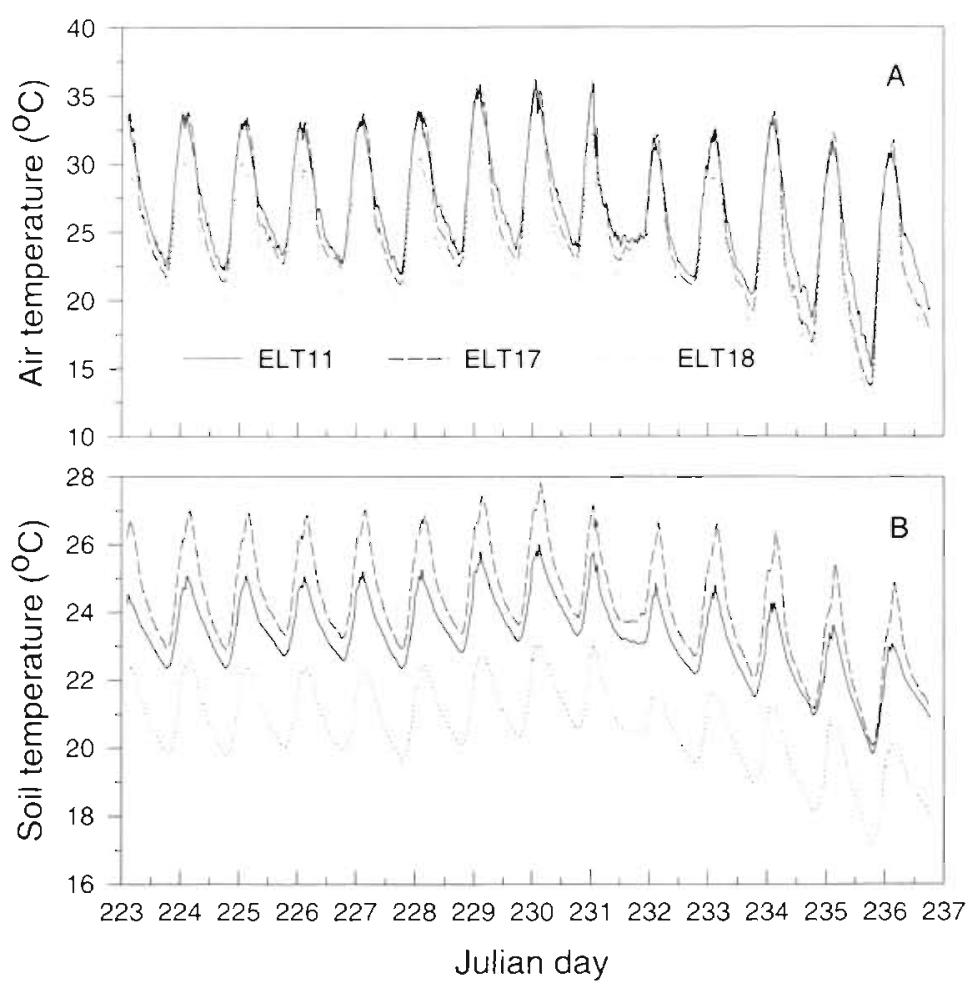

Fig. 8. Comparison of temperature features between ELT 11, 17 and 18 in Expt 2 (August 11 to 25, 1995). (A) Air temperature, (B) soil temperature

ature and 0.04 for soil temperature). Ground flora (herbs, shrubs, and vines) was more sensitive to temperature variation. At the $10 \mathrm{~m}$ scale, the correlation coefficients between temperature and species richness (no. of species $\mathrm{m}^{-2}$ ) were $-0.72,-0.42$, and -0.18 for air temperature, soil surface temperature, and soil temperature, respectively; corresponding correlation coefficients for Simpson's diversity index were $-0.53,-0.32$, and -0.13 . Simpson's diversity ranged from 0 to 2.6 , and it was highly correlated with species richness at the $400 \mathrm{~m}$ scale $\left(\mathrm{R}^{2}=0.99\right)$. Regression analyses showed that species richness and diversity of the ground flora were significantly related to air and soil surface temperatures $(p<0.004)$, but were not significantly related to soil temperature $(\mathrm{p}>$ $0.10)$. At the $10 \mathrm{~m}$ scale, air temperature explained more than half $\left(\mathrm{R}^{2}=52 \%\right)$ of the variation in species richness of the ground flora (Table 4).

With increasing spatial scale, the correlations between temperature, temperature variation, and species diversity varied considerably. The scale which resulted in the highest correlation was about $400 \mathrm{~m}$ for air and soil surface temperature, and around $500 \mathrm{~m}$ for soil temperature. At the $400 \mathrm{~m}$ scale, species richness and diversity were

\subsection{Effects of temperature and its variation on decomposition and species diversity}

Although the temperature in Expt $1\left(80 \times 80 \mathrm{~m}^{2}\right)$ was significantly different from one station to another, decomposition was not highly correlated with the spatial variation of temperature in this study [correlation coefficient (R) was 0.47 for air temperature and 0.62 for soil temperature]. Regression analysis showed that air temperature was not statistically significant in explaining the variation in decomposition ( $p=0.2)$, and soil temperature was not significant at a $95 \%$ confidence level but was significant at a $90 \%$ level $(p=0.07)$.

The overstory part of the oak-dominated forest was similar in species composition, $\mathrm{DBH}$, height, and canopy coverage along the $900 \mathrm{~m}$ transect. Temperature was poorly correlated with these indices of the overstory $(\mathrm{R}<0.27)$. Temperature was negatively correlated with the litter coverage on the forest floor $(R=-0.3$ for air temperature and -0.28 for soil temperature). Moss did not respond well to temperature variation at the stand level ( $\mathrm{R}$ was 0.01 for air temper-
Table 3. Temperature $\left({ }^{\circ} \mathrm{C}\right)$ and its variation within and between ELTs in Expt 2

\begin{tabular}{|ccccccc|}
\hline ELT & Mean & Mean & Maximum \\
& $T_{\mathrm{a}}$ & $T_{\mathrm{s}}$ & $T_{\mathrm{a}}$ & $\begin{array}{c}\text { Minimum } \\
T_{\mathrm{a}}\end{array}$ & $\begin{array}{c}\text { Maximum } \\
T_{\mathrm{s}}\end{array}$ & $\begin{array}{c}\text { Minimum } \\
T_{\mathrm{s}}\end{array}$ \\
\hline 11 & 26.76 & 23.29 & 36.21 & 15.12 & 26.03 & 19.82 \\
17 & 26.08 & 24.29 & 36.02 & 13.74 & 27.82 & 20.06 \\
18 & 24.12 & 20.66 & 32.35 & 12.65 & 23.07 & 17.17 \\
& & & & & &
\end{tabular}




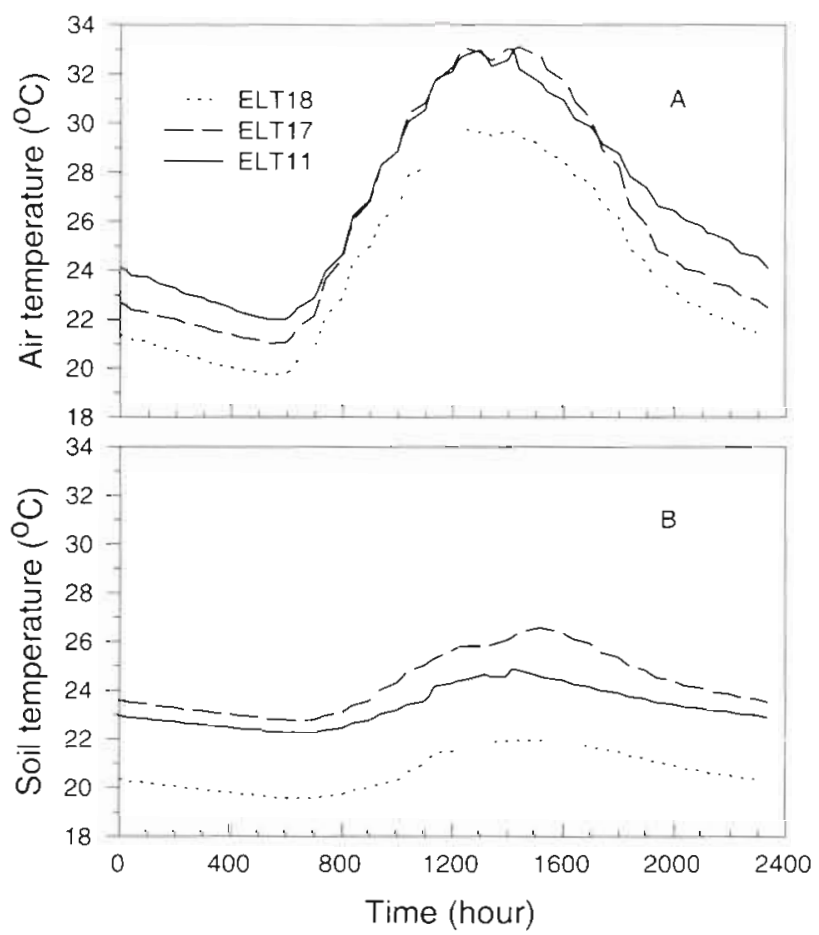

Fig. 9. Comparison of the diurnal pattern of (A) air temperature and (B) soil temperature between ELT 11, 17 and 18 in Expt 2 (August 11 to 25, 1995)

\section{DISCUSSION}

Both air temperature and soil temperature were significantly different within the same ELT. These results challenge the conclusion drawn by Hungerford \& Babbitt (1987) for the northern Rocky Mountains that surface condition does not appear to influence air temperature. Our results support the conclusion that temperature values for stands within the same vegetation type can be expected to vary (Zobel et al. 1976). Additionally, they agree with results reported by Chen et al. (1993) and Chen \& Franklin (1997) that temperatures can vary greatly at the stand level. Air and soil temperatures were strongly correlated within the same ELT. The mean, minimum and maximum soil temperature can be confidently estimated from the corresponding air temperature (Bocock et al. 1977, Dwyer et al. 1990). Significant differences existed for soil temperature measured at different depths $(0,5,10,15$, and $20 \mathrm{~cm})$, but differences were not significant for air temperature measured at small vertical scales $(0,0.5,1.0,1.5$, and $2.0 \mathrm{~m}$ above the soil surface). Within the same ELT, soil temperature had a larger spatial variation than air temperature, largely because air moves and mixes easily due to wind and turbulence. Air movement causes mixing of the air and the exchange of heat and energy among the molecules, and thus it reduces the spatial differences in air temperature. However, the mixing process does not result in a uniform temperature pattern because turbulence itself moves and distributes energy unevenly across the stand. This conclusion disagrees with Hungerford \& Babbitt's (1987) explanation that wind movement likely causes enough mixing to mask any differences in temperature, or Bergen's (1974) similar conclusion that the canopy and subcanopy air motion is sufficient to level out any local temperature differences generated by uneven radiation fields associated with canopy closure. On the other hand, the wind-induced movement of the forest canopy and the understory vegetation made insolation of the soil surface highly heterogeneous. This resulted in a greater spatial difference in soil temperature in the forest. Despite the differences, the spatial variation of soil temperature can be accurately estimated from the spatial variation of air temperature within the same ELT.

Temperatures in ELTs 11, 17 and 18 were significantly different $(p<0.001)$. Air temperature in ELT 17 was lower than in ELT 11, but higher than in ELT 18. The soil temperature in ELT 11 was lower than in ELT 17, but higher than in ELT 18 (Table 3). These conclusions do not agree with some earlier reports that slope and aspect have little effect on temperature (Kaufmann 1984). Furman (1978) also found that aspect had little effect on daily maximum temperature observed at a series of paired weather stations on either side of a forested ridge.

The spatial variation within different ELTs showed a 'twin-peak' phenomenon, especially for soil temperature. Of the 3 ELTs, ELT 17 had the highest temporal variation for both air and soil temperature. This might be explained by the low overstory density in ELT 17 (Table 2) resulting in exposure to more solar radiation. The temporal variation of air temperature was higher in ELT 11 than in ELT 18, but the reverse was true for soil temperature.

Spatial variation of temperature changed with spatial scale, and the spatial variation of soil temperature was always higher than that of air temperature at any spatial scale. Air temperature was different from soil temperature in responding to the spatial scale at the stand level. The spatial variation of soil temperature increased rapidly when the scale increased from 0 to about $40 \mathrm{~m}$, whereas the spatial variation of air temperature increased slowly at these scales (Fig. 11). The spatial variation of soil temperature decreased slowly from about 40 to $400 \mathrm{~m}$. The spatial variations of soil temperature and soil surface temperature were similar up to about $400 \mathrm{~m}$, then the latter began to increase, and the former kept stable before increasing after about $700 \mathrm{~m}$ (Fig. 11). Since soil temperature helps control nitrogen availability in the soil, this result may 


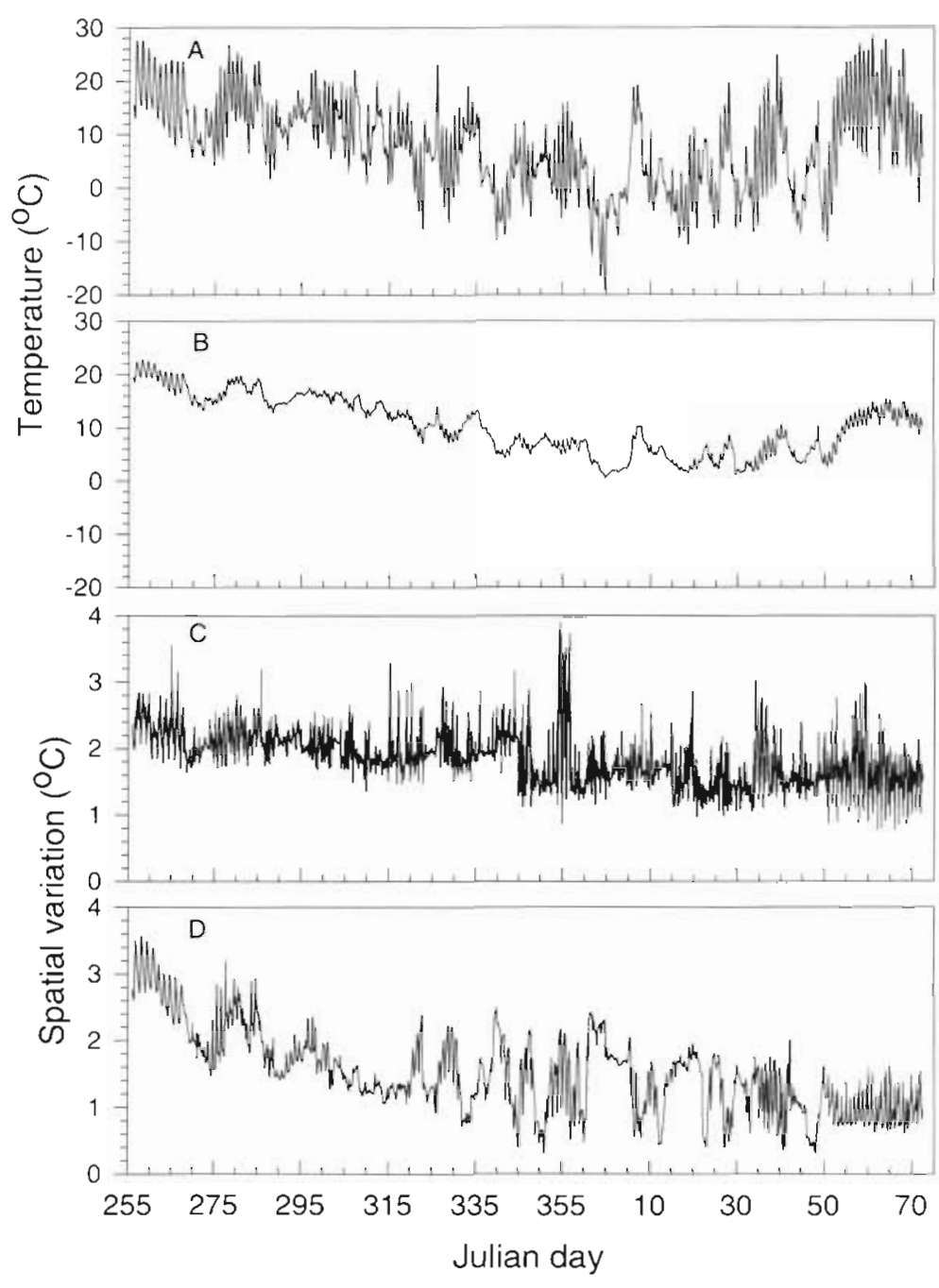

Fig. 10. Seasonal patterns of temperature and its spatial variation among the 9 MOFEP sites (Expt 3) from September 1994 to March 1995. (A, C) Air temperature, $(B, D)$ soil temperature ture increased with increasing spatial scale (Fig. 12). Because the wind-mixing process becomes less influential at large spatial scales, air temperature becomes more heterogeneous at broader scales. We noticed the spatial variation of soil temperature decreased from the stand level to the landscape level (Fig. 12). This was likely caused by the seasonal change of the forest canopy in Expt 3. From late fall to late spring, the trees (e.g. Quercus) shed their leaves. This makes the insolation to the soil surface more homogeneous than during the growing season. Therefore, the spatial variation of soil temperature should decrease from the stand to the landscape level as we found.

The temporal variations of both air and soil temperatures increased with spatial scale. This might have been caused by differences in fluctuation of the macroclimate during the different measured periods. Without the shading of the dense canopy in winter, the forest soil might receive relatively more insolation in the daytime and lose more energy during the night by increasing the effective terrestrial radiation (Rosenberg 1983). This can partly explain why the daily difference and the temporal variation of soil temperature increased during the winter.

Temporal scale influences the spatial variation of temperature (Fig. 13A). The spatial variation of soil temperature at the stand level was larger than that of air temperature at any given temporal scale. The vibration pattern of the spatial variation of temperature with increasing temporal scale was quite similar to damped oscillation (the amplitude of the wave gradually decreases to zerol. The amplitude of vibration decreased gradually with increasing temporal scale (Fig. 13A). At scales larger than about explain why more than $50 \%$ of the spatial variability of nitrogen availability has been found to be contributed at stand levels (Gross et al. 1995). The spatial variation of air temperature increased from 0 to about $200 \mathrm{~m}$, then it remained stable before increasing after about $550 \mathrm{~m}$ (Fig. 11). It is not clear why the spatial variation of soil temperature decreased from about 40 to about $600 \mathrm{~m}$. Further studies at broader spatial scales may provide more insights toward a final explanation.

The influence of scale on spatial variation can also be examined by comparing Expts 1 (small scale), 2 (stand level), and 3 (landscape level). The spatial variation of air tempera-
Table 4. Coefficients of determination $\left(\mathrm{R}^{2}\right)$ between species diversity of ground flora and temperature variation. TA = air temperature, $\mathrm{TSF}=$ soil surface temperature, TS $=$ soil temperature, $\sigma_{a}=$ spatial variation of air temperature, $\sigma_{s t}=$ spatial variation of soil surface temperature, $\sigma_{5}=$ spatial variation of soil temperature

\begin{tabular}{|cccccccc|}
\hline \multirow{2}{*}{ Scale $(\mathrm{m})$} & Index & TA & TSF & TS & $\sigma_{\mathrm{a}}$ & $\sigma_{\mathrm{sf}}$ & $\sigma_{\mathrm{s}}$ \\
\hline \multirow{2}{*}{10} & Species richness & 0.52 & 0.18 & 0.03 & - & - & - \\
& Simpson's index & 0.28 & 0.10 & 0.02 & - & - & - \\
\multirow{2}{*}{400} & Species richness & 0.99 & 0.97 & 0.94 & 0.91 & 0.92 & 0.74 \\
& Simpson's index & 0.99 & 0.98 & 0.95 & 0.87 & 0.92 & 0.79 \\
\hline
\end{tabular}




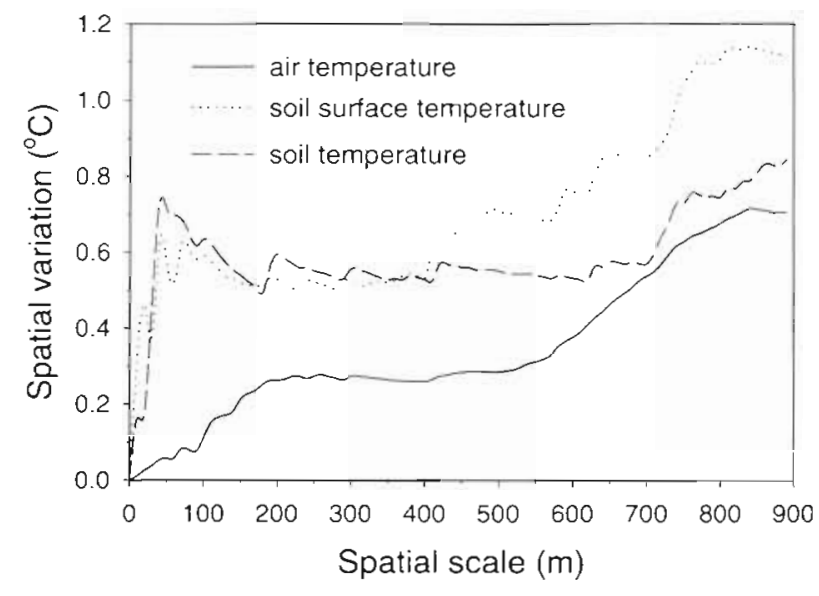

Fig. 11. Effects of spatial scale on the spatial variation of temperature within a stand using data collected every $10 \mathrm{~m}$ along a $900 \mathrm{~m}$ transect

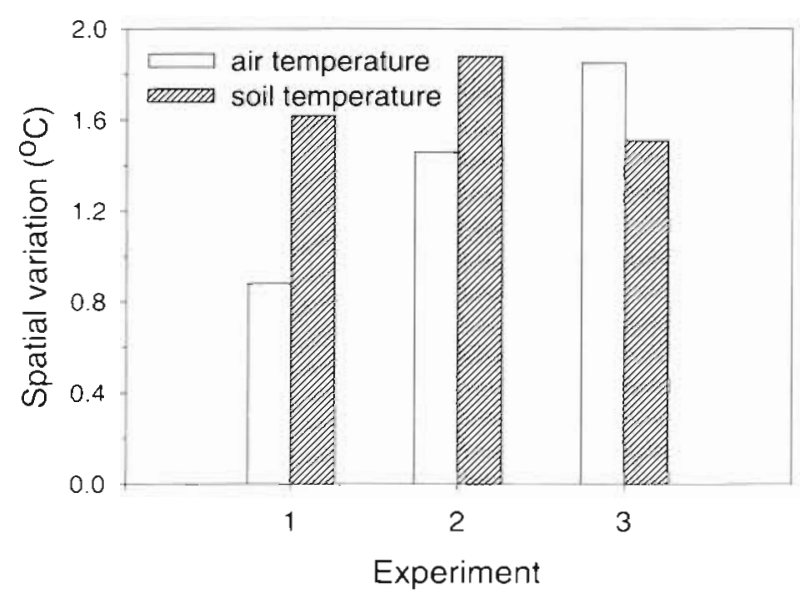

Fig. 12. Comparison of the spatial variations of temperature between Expt 1, 2 and 3 (from $80 \times 80 \mathrm{~m}^{2}$ to landscape level)

$150 \mathrm{~h}$ for soil temperature and $200 \mathrm{~h}$ for air temperature, the amplitude of the vibration stabilized, regardless of the initial points (Fig. 13A). The initial point affected the spatial variation greatly, especially at the small temporal scales (Fig. 13A). The curves with different initial points in Fig. 13A almost intersected each other near such temporal scales as 24,48 , and $72 \mathrm{~h}$. This suggests that the initial points had no effect on spatial variation at these temporal scales and that the day-based cycles (1-day, 2-day, 3-day, etc.) were dominant during the measurement period. Therefore, the daily average temperatures were more homogeneous in variance and less autocorrelated, and they can be treated as independent sampling points for statistical analyses.
Temporal scale also influences the temporal variation of temperature. The temporal variation of temperature increased rapidly with the increase in temporal scale. When the temporal scale was larger than $24 \mathrm{~h}$, temporal variation remained almost stable for soil temperature and decreased slowly for air temperature (Fig. 13B). This means the data were homogeneous in variance and less autocorrelated beyond this scale (24 h).

Temporal scale influences our ability to detect the spatial difference of temperature and its relationship to some ecological processes as well. The impacts of temperature on ecological processes are almost continuous over temporal scales (e.g. photosynthesis, respiration, and growth). Instant or small temporal-scale temperatures (e.g. 1, 5, 10, or $20 \mathrm{~min}$ average temperatures) may be more important for these ecological processes,
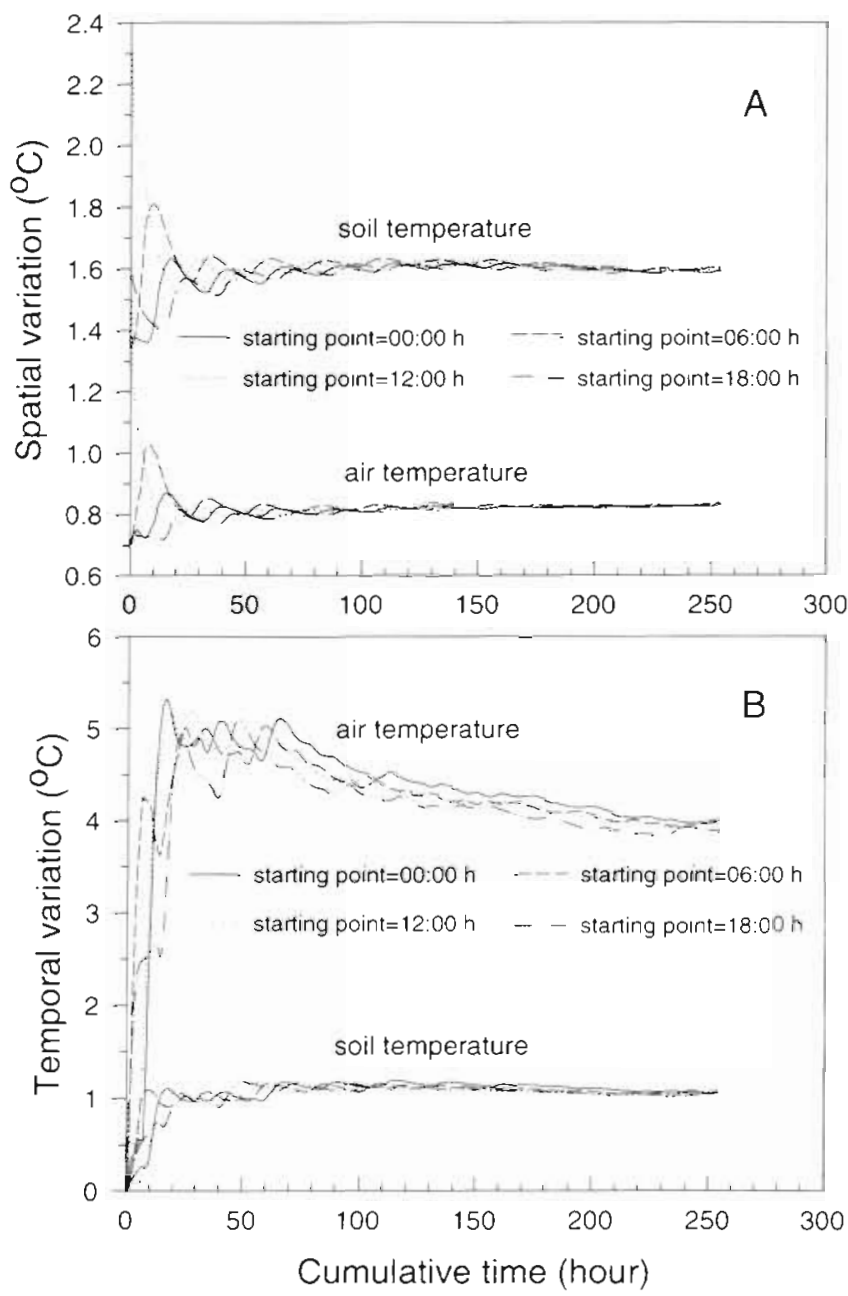

Fig. 13. Spatial and temporal variation of air and soil temperature at different temporal scales within a single ELT (Expt 1) (June 15 to 30, 1995). (A) Spatial variation, (B) temporal variation 
but it has not been paid much attention in previous studies. Although daily average (or day-based) temperature is more homogeneous in variance and less autocorrelated, it decreases our ability to detect the influence of temperature on some important ecological processes at small temporal scales. Fig. 14 demonstrates how critical the temporal scale is for detecting the spatial difference of temperature. Since the data are not normally distributed (from Expt 1), nonparametric statistical methods are used. In Fig. 14, $H$ is the statistic of the Kruskal-Wallis test with 8 degrees of freedom. When the temporal scale is smaller than about $5 \mathrm{~h}$ (according to Fig. 14), it can be concluded that the 9 stations are significantly different in temperature ( $\alpha=0.05$ ) according to the raw data (Fig. 14). However, when the temporal scale is larger than $5 \mathrm{~h}$, it is difficult to detect their differences (Fig. 14). Therefore, recording microclimate data at fine temporal scales is recommended for ecological purposes. Fig. 14 also shows the importance of data transformation. The transformed data can still detect the difference between the stations even if the temporal scale is larger than $5 \mathrm{~h}$ (Fig. 14)

Temperature and soil moisture, as reported in previous studies (Fox \& Van Cleve 1983, Erickson et al. 1985, Bonan \& Van Cleve 1992, Edmonds et al. 1995), are the most important and effective variables in predicting the decomposition rate on the forest floor because of their influences on microorganisms, $\mathrm{pH}$ values, and biochemical processes (Van Cleve et al. 1990). However, we did not detect a strong linear relationship between decomposition rate and temperature in this

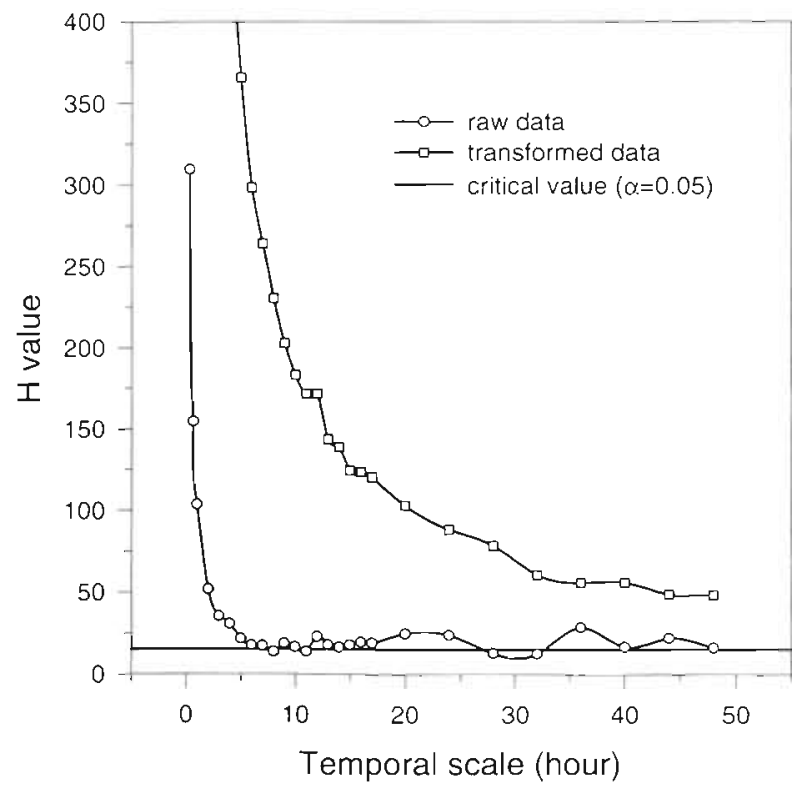

Fig. 14. Influence of temporal scale on the $H$ value of the Kruskal-Wallis test (Expt 1) study. Air temperature only explained $22 \%$ of the total variance in decomposition, while $38 \%$ was explained by soil temperature. Previous studies showed that the percentage ranged from 66 to 87 when using both temperature and moisture (precipitation) to predict decomposition rate in tundra ecosystems (Meal et al. 1974). This suggests that soil moisture and possibly the interaction between temperature and moisture are more critical in determining the decomposition rate in the study area. An alternative explanation is that there may exist a nonlinear relationship between the strength of the cotton strip and the organic decomposition rate. This may reduce the accuracy in quantifying the relationship between temperature and decomposition. Moreover, a nonlinear relationship may exist between temperature and decomposition rate (Meal et al. 1974, Rosswall 1974, Inerson et al. 1988).

Surprisingly, we found that the species diversity of the ground flora was negatively correlated with temperature and its spatial variation. Possible explanations may include: (1) the high temperature during the measurement period (summer) might be harmful to some ground flora; (2) high temperature was generally related to the poor and dry soils in our study area, which might reduce species diversity (Zobel et al. 1976); (3) the high spatial variation of temperature was generally related to high temperature, which resulted in negative effects on species diversity $\left(\mathrm{R}^{2}=\right.$ $0.87,0.93$, and 0.76 for air, soil surface, and soil temperature, respectively) (Chen \& Franklin 1997). For example, high species diversity was normally found in flat valleys or on north slopes where soil was deeper and wetter, and temperature and its variation were lower.

\section{CONCLUSIONS}

Temperature can vary considerably in oak-dominated forests depending on spatial and temporal scales. Temperature and its variation can differentiate some ecological processes even at the stand scale, and their influence is also scale dependent. We suggest that scale effects must be taken into account when examining the effects of temperature on ecological processes. Although the results of this study are based on data specific to oak forests in southeastern Missouri, some of the conclusions may be applied to other temperate forests. However, some of the conclusions (e.g. the effects of temperature and its variation on decomposition and species diversity) may be different in other regions.

This paper focuses on temperature and its variation at the stand level. In order to show the ecological significance of the spatial variation of temperature, we 
examined the relationships between temperature variation and decomposition and species diversity. Results showing that the spatial variation of temperature is poorly correlated with decomposition rate and negatively correlated with species diversity suggest that the relationship between spatial heterogeneity of the environment and ecological patterns and processes (e.g. species diversity) is complicated because of the interactions between many environmental variables; separating out the effects of 1 factor is usually difficult and subject to bias. Therefore, multidisciplinary cooperation is recommended when some ecological patterns and processes are studied at the ecosystem or landscape level.

Acknowledgements. Field assistance was generously given by John Avouris, Jennifer Grabner, Randy Jenkins, Mike Morris, Lorren Leatherman, and Terry Robison, and their help is appreciated. The authors thank Dr Jianping Dong for providing helpful suggestions concerning the data analysis. We also thank Dr Steve Lowe, Dr Eric Heitzman. Kim Brosofske, and 3 anonymous reviewers for their suggestions and comments on the draft. Financial support for this research was provided by the Missouri Department of Conservation.

\section{LITERATURE CITED}

Albert D (1995) Regional landscape ecosystems of Michigan, Minnesota, and Wisconsin: a working map and classification. USDA For Ser Gen Tech Rep NC-178

Alexander $M$ (1961) Introduction to soil microbiology. John Wiley \& Sons, Inc, New York

Barker JSF, Starmer WT, Vacek DC (1987) Analysis of spatial and temporal variation in the community structure of yeasts associated with decaying Opuntia cactus. Microb Ecol 14:267-276

Barnes BV, Pregitzer KS, Spies TA, Spooner VH (1982) Ecological forest site classification. J For 80:493-498

Bergen JD (1974) Variation of air temperature and canopy closure in a lodgepole pine stand. USDA For Ser Res Pap RM-253

Bocock KL, Jeffers JNR, Lindley DK, Adamson JK, Gill CA (1977) Estimating woodland soil temperature from air temperature and other climatic variables. Agric Meteorol 18 : $351-372$

Bonan GB, Van Cleve K (1992) Soil temperature, nitrogen mineralization, and carbon source-sink relationships in boreal forests. Can J For Res 22:629-639

Brock TD (1966) Principles of microbial ecology. PrenticeHall, Inc, Englewood Cliffs, NJ

Brookshire B, Hauser C (1993) The Missouri Ozark Forest Ecosystem Project: the effect of forest management on the forest ecosystem. Internal Publications of Missouri Department of Conservation, Jefferson City, p 21-41

Chen J, Franklin JF (1997) Growing-season microclimate variability within an old-growth Douglas-fir forest. Clim Res 8(1):21-34

Chen J, Franklin JF, Spies TA (1993) An empirical model for predicting diurnal air-temperature gradients from edge into old-growth Douglas-fir forest. Ecol Model 67:179-198

Christensen NL, Bartuska AM, Brown JH, Carpenter S, Antonio C, Francis R, Franklin JF, MacMahon JA, Noss
$\mathrm{RF}$, Parsons DJ, Peterson $\mathrm{CH}$, Turner $\mathrm{MG}$, Woodmansee RG (1996) The report of the Ecological Society of America committee on the scientific basis for ecosystem management. Ecol Appl 6(3):665-691

Davis FW, Dozier J (1990) Information analysis of a spatial database for ecological land classification. Photogramm Eng Remote Sensing 56(5):605-613

Day FP (1995) Environmental influences on belowground decomposition on a coastal barrier island determined by cotton strip assay. Pedobiologia 39:289-303

Dickmann DI, Pregitzer KS (1992) The structure and dynamics of woody plant root systems. In: Mitchell CP, FordRobertson JB, Hinckley T, Sennery-Forsse L (eds) Ecophysiology of short rotation forest crops. Elsevier Applied Science, New York

Dwyer LM, Hayhoe HN, Culley JLB (1990) Prediction of soil temperature from air temperature for estimating corn emergence. Can J Plant Sci 70:619-628

ECOMAP (1993) National hierarchical frame-work of ecological units. USDA. For Ser Pap, Washington, DC, p 20

Edmonds RL, Thomas TB (1995) Decomposition and nutrient release from green necdles of western hemlock and Pacific silver fir in an old-growth temperate rain forest, Olympic National Park, Washington. Can J For Res 25(7): $1049-1057$

Erickson HE, Edmonds RL, Peterson CE (1985) Decomposition of logging residues in Douglas-fir, western hemlock, Pacific fir, and ponderosa pine ecosystems. Can J For Res $15: 914-921$

Faulkner HG (1976) Root distribution, amount, and development from 5-year-old Populus $x$. euramericana (Dode) Guinier. MSF thesis, University of Toronto

Fox JF, Van Cleve K (1983) Relationship between cellulose decomposition, Jenny's $k$, forest-floor nitrogen, and soil temperature in Alaskan taiga forests. Can J For Res 13: $789-794$

Franklin JF (1997) Ecosystem management: an overview. In: Boyce MS, Haney A (eds) Ecosystem management. Applications for sustainable forest and wildlife resources. Yale University Press, New Haven, p 21-53

Furman RW (1978) Wildfire zones on a mountain ridge. Ann Assoc Am Geogr 68:89-94

Futuyma DJ (1986) Evolutionary biology. Sinauer Associates, Sunderland, MA

Gibbons JD (1985) Nonparametric methods for quantitative analysis, 2nd edition. American Sciences Press, Inc, Columbus, $\mathrm{OH}$

Gordon MS, Bartholomew GA, Grinnell AD, Jorgenson CB, White FN (1977) Animal physiology: principles and adaptations, 3rd edn. Macmillan Publishing Co, Inc, New York

Gott J (1975) Soil survey of the Mark Twain National Forest Area, Missouri (parts of Carter, Oregon, Ripley and Shannon counties. USDA Forest Service, Rolla, MO

Gross KL, Pregitzer KS, Burton AJ (1995) Spatial variation in nitrogen availability in tree successional plant communities. J Ecol 83:357-367

Haeuber R, Franklin JF (1996) Perspective on ecosystem management. Ecol Appl 6(3):692-693

Hanson DS, Hargrave B (1996) Development of a multilevel ecological classification system for the state of Minnesota. Environ Monit Assess 39(1-3):75-84

Hatano K, Asakawa S (1964) Physiological processes in forest tree seeds during maturation, storage, and germination Int Rev For Res 1:279-323

Heal OW, Howson G, French DD, Jeffers JN (1974) Decomposition of cotton strips in tundra. In: Holding AJ et al. (eds) Soil organismsm and decomposition in tundra. Tundra 
Biome Steering Committee, Stockholm, p 341-362

Host GE, Polzer PL, Mladenoff DJ, White MA, Crow TR (1996) A quantitative approach to developing regional ecosystem classifications. Ecol Appl 6(2):608-618

Host GE, Pregitzer KS, Ramm CW, Lusch DP, Cleland DT (1988) Variation in overstory biomass among glacial landforms and ecological land units in northwestern Lower Michigan. Can J For Res 18:659-668

Hungerford RD, Babbitt RE (1987) Overstory removal and residue treatments affect soil surface, air, and soil temperature: implications for seedling survival. USDA For Ser Res Pap INT-377

Hunter ML (1990) Wildlife, forest, and forestry. Prentice Hall Career \& Technology, Englewood Cliffs, NJ

Inerson P, Bacon PJ, Lindley DK (1988) Decomposition of cotton strips in soil: analysis of the world data set. In: Harrison AF, Latter PM, Walton DWH (eds) Cotton strip assay: an index of decomposition in soils. ITE Symposium No. 24 Natural Environment Council, Institute of Terrestrial Ecology, Cumbria, p 155-165

Johansson MB, Berg B, Meentemeyer V (1995) Litter massloss rates in late stages of decomposition in a climatic transect of pine forests. Long-term decomposition in a Scots pine forest. Can J Bot 73(10):1509-1521

Kanninen M (1985) Shoot elongation in Scots pine: diurnal variations and response to temperature. J Exp Bot 36:1760-1770

Kaufmann MR (1984) Effects of weather and physiographic conditions on temperature and humidity in subalpine watersheds of the Fraser Experimental Forest. USDA. For Ser Res Pap RM-251:9

Kramer PJ, Kozlowski TT (1979) Physiology of woody plants Academic Press, New York

Kuhns MR, Garrett HE, Teskey RO (1985) Root growth of black walnut trees related to soil temperature, soil water potential, and leaf water potential. For Sci 31:617-629

Latter PM, Walton DWH (1988) The cotton strip assay for cellulose decomposition studies in soil: history of the assay and development. In: Harrison AF, Latter PM, Walton DWH (eds) Cotton strip assay: an index of decomposition in soils. ITE Symposium No. 24. Natural Environmental Council, Institute of Terrestrial Ecology, Cumbria, p 7-10

Lee R (1987) Forest microclimatology. Columbia University Press, New York

Lowell KE (1990) Differences between ecological land type maps produced using GIS or manual cartographic methods. Photogramm Eng Remote Sensing 56(2):169-173

Miller MR (1981) Ecological land classification terrestrial subsystem - a basic inventory system for planning and management of the Mark Twain National Forest. USDA Forest Service Rolla, MO, p 65

Missouri Geological Survey (1979) Stratigraphic succession in Missouri. Missouri Dept of Natural Resources, Rolla, MO

Editorial responsibility: Brent Yarnal, University Park, Pennsylvania, USA
Mulley JC, James JW, Barker JSF (1979) Allozyme genotypeenvironment relationships in natural populations of Drosophila buzzatii. Biochem Genet 17:105-126

Pickett STA, Cadenasso ML (1995) Landscape ecology: spatial heterogeneity in ecological systems. Science 269: $331-334$

Rosenberg NJ (1983) Microclimate: the biological environment. John Wiley \& Sons, New York

Rosswall T (1974) Cellulose decomposition studies on the tundra. In: Holding AJ et al. (eds) Soil organisms and decomposition in tundra. Tundra Biome Steering Committee, Stockholm, p 325-340

Sagar BF (1988) The Shirley Soil Burial Test Fabric and tensile testing as a measure of biological breakdown of textiles. In: Harrison AF, Latter PM, Walton DWH (eds) Cotton strip assay: an index of decomposition in soils. ITE Symposium No. 24. Natural Environmental Council, Institute of Terrestrial Ecology, Cumbria, p 11-16

Sorensen FC (1983) Relationship between logarithms of chilling period and germination or bud flush rate is linear for many tree species. For Sci 29:237-240

Spies TA, Barnes BV (1985) A multifactor ecological classification of the northern hardwood and conifer ecosystems of Sylvania Recreation Area, Upper Peninsula, Michigan. Can J For Res 15:949-960

Taylor CE, Powell JR (1977) Microgeographic differentiation of chromosomal and enzyme polymorphisms in Drosophila persimilis. Genetics 85:681-695

Thomas JW (1996) Forest service perspective on ecosystem management. Ecol Appl 6(3):703-705

USDA (1979) Eastern region land and resource management planning handbook. USDA For Ser Handb 1909.21

Van Cleve K, Oechel WC, Hom JL (1990) Response of black spruce (Picea mariana) ecosystems to soil temperature modification in interior Alaska. Can J For Res 20(9): $1530-1535$

Waring RH (1969) Forest plants of the Eastern Siskyous: their environmental and vegetational distribution. Northwest Sci $43: 1-17$

Waring RH, Schlesinger WH (1985) Forest ecosystems: concepts and management. Academic Press, Orlando

Wilson RG (1970) Topographic influences on a forest microclimate. Clim Res Ser 5. McGill University, Montreal

Zak DR, Pregitzer KS, Host GE (1986) Landscape variation in nitrogen mineralization and nitrification. Can J For Res 16: $1258-1263$

Zimmermann MH, Brown CL, Tyree MT (1971) Trees-structure and function. Springer-Verlag, New York

Zobel DB, Mckee A, Hawk GM, Dyrness CT (1976) Relationships of environment to composition, structure, and diversity of forest communities of the central western Cascades of Oregon. Ecol Monogr 46:135-156

Manuscript first received: October 17, 1996

Revised version accepted: April 22, 1997 